\title{
The Use of Documentary Film Text in Developing Arabic Writing Skills: What the Experts Say
}

\author{
Tg Ainul Farha Tg Abdul Rahman* \& Abdul Rahman Chik \\ Department of Arabic Language and Literature, Kulliyyah of Islamic Revealed Knowledge and Human Sciences, \\ International Islamic University Malaysia, 53100 Kuala Lumpur, Malaysia \\ Muhammad Sabri Sahrir \\ Department of Language and Literacy, Kulliyyah of Education, International Islamic University Malaysia, \\ 53100 Kuala Lumpur, Malaysia
}

\begin{abstract}
Documentary film is a language input which is based on writing skills since it consists of the introduction to subject, presentation of ideas, and conclusion of subject. Many studies have highlighted the linguistic, informational, and pedagogical purposes of documentary film in language classrooms as the processing of written texts is required before the production of a documentary film. Although documentary film has a strong relationship with writing skills and having access to these authentic materials are very easy, some educators ignore these authentic inputs. Thus this paper investigates the importance of using documentary film in enhancing the learning of Arabic as a second language with specific focus on writing skills. In addition, this paper examines local experts' views on the utilization of documentary film in the Arabic as a second language classroom. A set of questionnaire with both open and closed-ended questions were distributed among twelve experts in the field of Arabic as a second language in Malaysian public universities. Feedbacks from the experts were collected and analyzed. The findings indicated strong recommendations from Arabic language experts in Malaysia. Among the recommendations are the types of documentary films to be utilized, the categories of writing skills that can be developed, and the appropriate instructional techniques to be used in the classroom. In general, this study hopes to contribute to the field of Arabic teaching language skills to non-native speakers and a useful reference for curriculum designers, ministry officials, textbook authors, and teachers.
\end{abstract}

Keywords: Multimedia learning, documentary films, Arabic language, writing skill, expert review

\subsection{INTRODUCTION}

The importance of language input in the acquisition of a second language is not something new. The issue has been discussed in different educational stages in schools, institutions, and universities. This issue has been highlighted by Krashen (1985) in describing the role of input hypothesis in second language acquisition. By understanding the input which contains structure at a higher level, 
progress along a natural order, where the structure a bit beyond the current level of competence is achieved (Krashen, 1985). Krashen (1985) suggested comprehensive input as a potential type of language input and is the main feature in all cases of effective second language acquisition (SLA), where by more quantities of comprehensive input seem to cause faster or better second language acquisition while lack of access to comprehensive input causes little or no second language acquisition (Bahrani, 2013). Authentic language inputs are ready and not for the purpose of education only, but also for social purposes because these texts share the real language used by the native speakers. The original texts are based on the technical language used in the press and media in general and highlight the characteristics which encompass linguistic and stylistic aspects and are not aesthetic art in itself, with the purpose of communicating with people and the transferring of meanings as well as ideas to them (As-Sayyed, 2006). In the field of teaching and learning language skills, verbal communication skills are the inputs to the outputs of literacy skills. At the same time, the researcher does not reject the relationship between these four skills in language classes. The input of Arabic language required in the teaching and learning process is an authentic input to the language of any authentic text, whether it is spoken or written. Listening is related to writing because someone cannot write the specific subject unless he listened to it, or a similar position, knew what he listened to. Thus, the listening role in the experience keeps some mental images until they are used. Similar to listening and writing, the analysis of the subject to be written includes its elements, ideas, syntax, structures, paragraphs, and vocabulary. Then, the message is composed and is followed by another analysis process to revise the written work. The base of this study of using documentary film is the cognitive theory of multimedia learning which can be defined as the presentation of material using both words and pictures (Mayer, Heiser \& Lonn, 2001). In this theory, the student engages in three important cognitive processes which are selecting, organizing, and integrating (Mayer \& Moreno, 1998).

Alnufaie and Grenfell (2012) stated that writing is viewed as a complex cognitive skill, decisionmaking and problem-solving activity from the cognitive perspective. Thus, the cognitive writing process presented attempts to account for the major thinking processes and constraints during writing. The act of writing involves three major elements that are reflected in the three units of the model: the task environment, the writer's long-term memory, and the writing processes (Flower \& Hayes, 1981). In this research, the role of the documentary film as the authentic input in writing process satisfied the role of the task environment which is one of the three units of cognitive process theory (Tg Ainul Farha et al., 2017). The writer or speaker should first define the topic, identify the objectives to be achieved by speaking or writing, and identify ideas and paragraphs, sentences, and phrases. The author uses the punctuation marks which act as sound tones or speaker tones while speaking. Meanwhile, the speaker sends out words, sentences, and phrases, and impulsively sends thoughts. 


\subsection{LITERATURE REVIEW}

Various experts revealed that documentary films can potentially enhance language skills in second language learning among learners, including writing skill. Below is the theoretical foundation of this study.

\section{Documentary Film as Language Input}

Many studies have highlighted the linguistic, informational (Morley \& Lawrence, 1971), and pedagogical purposes of documentary film in facilitating language skill learning. The linguistic purpose is to provide advanced students with opportunities for live practice in the four skills of language. Peacock's (1997) study recommended lecturers to use appropriate authentic materials in their classrooms as they may increase their students' levels of on-task behaviour, concentration, and involvement in the target activity more than when using artificial materials. In order to capitalize on a student's inherent interest in the Italian culture, Joynt used documentary film in her language study (Joynt, 2008). Bernardo (2011) believed that documentary films were chosen as a learning tool because they are potential medium in enhancing higher-order thinking skills. Using documentary film in an English oral interpretation class, some important findings are drawn which indicated that the use of documentary films in class can easily meet the need for authenticity and communication (Soong, 2012). Shin \& Cho (2015) found that the students' experience change in cognition and emotions from fear to pleasure.

\section{Documentary Film and Writing Skill}

Several studies have proved that employing documentary films in second language writing class has value. For example, "Tsunami Japan" was an effective documentary film to be used in a writing class (Hassan Basri, 2011) and natural disaster and technology documentary films are helpful to write news text (Haris \& Abdullah, 2013). In addition, "natural and environment" documentary films (Rohman, 2014) and documentary films about animals, plants, cities, and the last natural disaster (Hutahaean \& Ernidawati, 2013) help students in writing report texts. In other studies, Snow (2012) used four types of documentaries which are expository, observational, interactive, and reflective to explore the similarities between all these types of documentary film and essay composition. Morley and Lawrence (1971) reached the conclusion that there is mutual interdependence between listening ability and writing ability and it seems likely that students who are taught how to listen will find it easier to communicate their ideas in writing. Critical thinking in writing exposition is also mentioned by Kasper (2000) who found that film imagery enables students to visually process comparative and casual relationships between and among issues and events and also encourages students to support points of view on an issue.

Some studies have been conducted to prove the relationship between film and writing skills. Baratta and Jones (2008) proved that selected films which include Halloween, Diamonds are Forever, Star Wars Episode III: Revenge of the Sixth have helped university students in writing in terms of introducing students to concepts such as textual cohesion and coherence. Indrasari (2010) concluded 
that the film The Postman Pat and Surprise Present has improved students in the aspect of social function and generic structure of narrative text. Tristy (2010) proved that the "All about animals" VCD is very useful to teach students in writing report texts. Anggraini, Yasin, and Radjab (2014) highlighted an improvement in narrative text writing in terms of content, organization, vocabulary, grammar, and mechanics from the video multimedia. In conclusion, the previous studies have highlighted and proven the importance of documentary films as an instructional material in enhancing language writing skills from various aspects.

\section{Instructional Model and Employment of Documentary Film in Enhancing Language Writing Skill}

A model is needed to use this type of multimedia material in a writing class. Morley \& Lawrence (1971) have suggested five steps in using documentary film to enhance the four language skills among second language students. Step 1 is the preparation for aural comprehension while the second step is aural comprehension and class discussion. These two steps cover listening and speaking skills. Step 3 requires an advanced preparation for writing while the fourth composition step is composition exercise. These two steps cover writing skills. The last step involves the supplementary reading of selected articles (Morley \& Lawrence, 1971). Another instructional model is proposed by Jeremiah (1987) who suggested 12 steps to empoy the news segment and documentary films in writing sentences and content for an essay topic. This study suggested that the teacher can complete a lesson between 45 and 60 minutes.

The next instructional model is by Baratta \& Jones (2008) who have discussed that the first step is students watching the film's opening and then answering two writing-guide questions before writing the introduction of the essay. The second step is to locate the thesis statement and watch the film. After that, the students answer two writing-guide questions before determining unity and sentence cohesion. Lastly, students watch a section of the film and students answer two writing-guide questions before determining the structure and coherence (Bilal, 2013). Berk's Model is the fourth instructional model which proposes the utilization of multimedia aids in the classroom (Berk, 2009). From his 12 steps, this research can benefit in the aspect of providing stimulus for the learning activities in the class by practicing open discussion, small group collaboration, and think-pair-share activities among students (Berk, 2009). The last instructional model is suggested by Hasan Basri (2011) who allocated 45 minutes for each class for each step. The first step is to allow the students to watch a documentary film and ask them to make notes of the events. In the next phase, the teacher explains generic structures and students watch the documentary video again before the teacher asks them to discuss the generic structure of the documentary film in pairs. Then, the teacher explains the linguistic features and students watch the documentary video again before the teacher asks them to analyze the documentary film. In the last step, the teacher makes a revision of the previous lessons before the students complete the composition task. 


\subsection{RESEARCH OBJECTIVES AND METHODOLOGY}

This study aims to present the importance of using documentary film in enhancing Arabic as a second language (ASL) writing skill and discuss the perceptions of Arabic language experts in Malaysia towards the use of documentary texts in the development of writing skills among students majoring in the Arabic language. To achieve these two objectives, the study implements quantitative and qualitative data collection methods within a survey design (Amaya-Anderson, 2008). In this crosssectional study, the researchers selected the survey method using a questionnaire to examine current attitudes, beliefs, opinions, or practices of subject matter experts (SMEs) regarding the use of documentary films in the writing skill classroom. Mailed questionnaires were sent to the respondents which consist of an official cover letter from the Department of Arabic language and literature and the link of the electronic questionnaire via Google form (http://bit.ly/lHHAzfX) is attached (Reja, Manfreda, \& Hlebec, 2003). That questionnaire is a constructed instrument of appropriate length that contains an opening beginning with demographic questions, a series of open-ended and closed-ended questions (Creswell, 2012). The questionnaires were then distributed among twelve experts in the field of Arabic as a second language in Malaysian public universities who are purposively selected for this study. This sampling method is also affordable and easy as the SMEs are readily available (Etikan, Musa \& Alkassim, 2016) (See Table 1).

Table 1 The Demographic Data of Arabic Subject Matter Experts

\begin{tabular}{|c|c|c|}
\hline No & Specialization & University \\
\hline 1 & $\begin{array}{c}\text { Arabic Linguistics } \\
\text { Studies }\end{array}$ & $\begin{array}{c}\text { International Islamic University Malaysia } \\
\text { (Kuliyyah of Languages and Management) } \\
\text { Universiti Kebangsaan Malaysia } \\
\text { Universiti Putra Malaysia } \\
\end{array}$ \\
\hline 2 & $\begin{array}{l}\text { Arabic Language } \\
\text { Education }\end{array}$ & $\begin{array}{c}\text { Institut Perguruan Islam Bangi } \\
\text { Universiti Pendidikan Sultan Idris } \\
\text { Kolej Universiti Islam Antarabangsa Selangor } \\
\text { Kolej Universiti Insaniah } \\
\end{array}$ \\
\hline 3 & Arabic Language & $\begin{array}{c}\text { Universiti Sultan Zainal Abidin } \\
\text { Universiti Malaya } \\
\text { Universiti Sains Islam Malaysia } \\
\end{array}$ \\
\hline 4 & $\begin{array}{c}\text { Instructional } \\
\text { Technology (Arabic) }\end{array}$ & $\begin{array}{c}\text { Universiti Teknologi MARA } \\
\text { International Islamic University Malaysia } \\
\text { (Kuliyyah of Education) }\end{array}$ \\
\hline
\end{tabular}

\subsection{FINDINGS AND DISCUSSION}

The results of this study are presented by using qualitative and quantitative data. The interpretation of results was done based on a key to understand the average as proposed by Rebecca Oxford (1990). The mean score of 4.5-5.0 is interpreted as to be very high while the mean score between 3.5 and 4.4 is interpreted as high. The mean score of 3.4-2.5 is interpreted as a medium while the mean score between 2.4 and 1.5 is interpreted as low. Finally, the mean score of 1.0-1.4 is interpreted as very low. 
The qualitative data in this paper are used to support the quantitative data as proposed by Popping (2015). The qualitative findings are presented in visual displays (Verdinelli, \& Scagnoli, 2013). The results and findings are presented in four parts. The four parts refer to the contribution of documentary film as a writing skill input, the Arabic writing skills that can be enhanced through documentary film, suggested areas to be employed in future research, and suitable instructional model to be used.

\section{The Contribution of Documentary Film as Writing Skill Input}

Both quantitative and qualitative results and findings are analyzed to find out from SMEs the contribution of documentary film as writing skill input. From the SMEs feedback in Figure 1, it is apparent that they agreed with the seven items as the mean score between 4.58 and 3.92 , is interpreted as very high while the remaining five skills are indicated at high interpretation only. This result shows that Arabic SMEs in Malaysian Institutions agreed with the contributions of documentary films as an authentic input in language learning as stated in several studies done in other language settings (Bernardo, 2011; Soong, 2012; Morley \& Lawrence, 1971; Shin \& Cho, 2015; Peacock, 1997; Joynt, 2008). In addition, from the open-ended findings as portrayed in Figure 2, it can be observed that SMEs suggested looking for types of documentary film which either have texts or subtitles. They also agreed that documentary films as an authentic input will contribute to new knowledge and acquired vocabulary, cultural information, and academic expression. However, the teachers and students need to be more focused and trained in utilizing this type of media during the learning and teaching process.

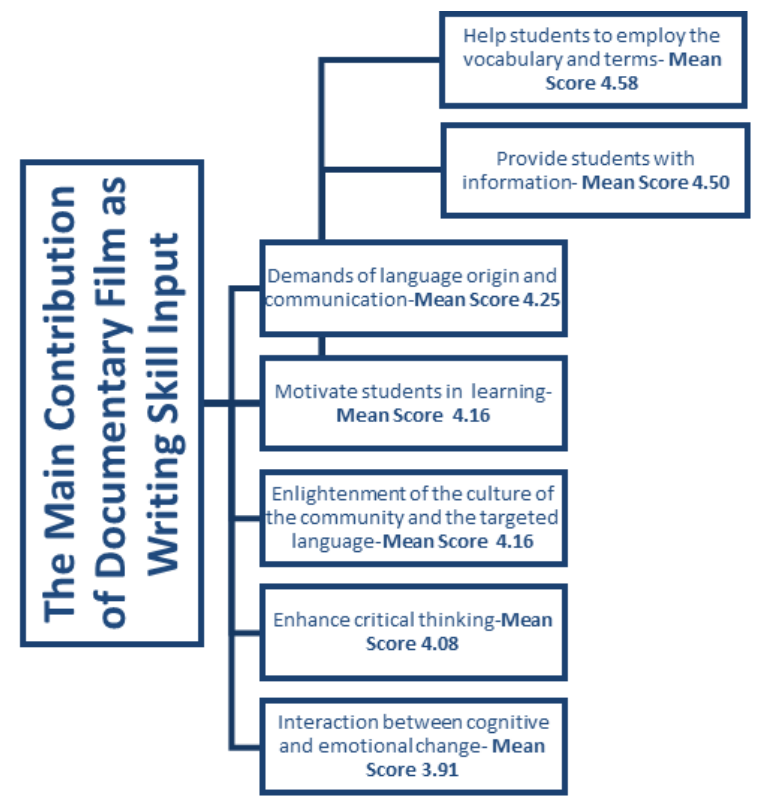

Figure 1 The Contribution of Documentary Film as Writing Skill Input 


\begin{tabular}{|c|c|c|c|}
\hline $\begin{array}{l}\text {-Good work and } \\
\text { recommended to } \\
\text { be } \\
\text { implemented.-E2 } \\
\text { - The employment } \\
\text { of documentary } \\
\text { film is good.-E9 } \\
\text {-The employment } \\
\text { of documentary } \\
\text { films in the } \\
\text { writing skills class } \\
\text { is good.-E5 } \\
\text { - No doubt that } \\
\text { the authentic } \\
\text { text from } \\
\text { documentary } \\
\text { films is important } \\
\text { and has a } \\
\text { positive role in } \\
\text { improving writing } \\
\text { skills.-E3 } \\
\text {-The application is } \\
\text { excellent.-E1 }\end{array}$ & 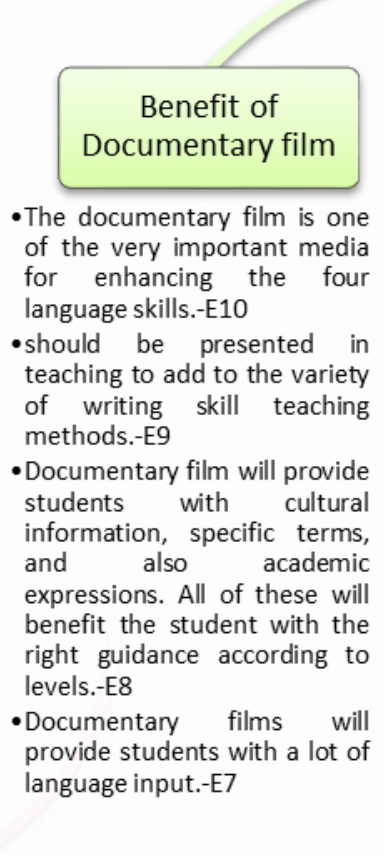 & 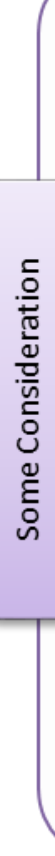 & $\begin{array}{l}\text {-The researchers have to search for this information } \\
\text { from literature review, especially in peer-reviewed } \\
\text { journals written in the field of teaching and } \\
\text { learning English as second or foreign language.-E12 } \\
\text { - The documentary films will benefit students with } \\
\text { good preparation.-E11 } \\
\text { - There is a need to carefully choose the } \\
\text { documentary films to make sure that the objective } \\
\text { is achieved.-E6 } \\
\text { - Watching documentary films needs more focus and } \\
\text { training on listening because usually the reporter } \\
\text { explains in speed speaking.-E4 } \\
\text {-the text provides students with new vocabulary } \\
\text { and also areas of new knowledge. The good writer } \\
\text { who increases this reading area.-E3 } \\
\text { - some considerations: } \\
\text {-1-Are Arabic documentaries available on Malaysian } \\
\text { TV channels? } \\
\text {-2- How can students obtain documentary film texts } \\
\text { benefit from them? } \\
\text { - } 3 \text { - Do these documentary film texts appear on the } \\
\text { screen to give students the opportunity to read and } \\
\text { take advantage of the texts? } \\
\text { - } 4 \text { - Are these documentary films translated into } \\
\text { Arabic, and do translated texts appear on the } \\
\text { screen? }\end{array}$ \\
\hline
\end{tabular}

Figure 2 Other Contributions of Documentary Film as a Writing Skill Input

In conclusion, based on the data from both quantitative and qualitative methods, the researchers found that the SMEs contributed valuable ideas when the contributions of authentic texts from documentary films are discussed. The SMEs suggested looking for certain types of documentary film, and ensure if the films have texts or subtitles. They also agreed that documentary films as an authentic input will contribute to new knowledge and vocabulary, cultural information, and academic expression. However, there is a need for more focus and training in utilizing this type of media during the learning and teaching process. It shows that the authentic texts in documentary films are able to provide good input in language learning where opportunities for learners to learn through both words and pictures (Mayer, Heiser \& Lonn, 2001) and comprehensive input as a potential type of language (Krashen, 1985).

\section{The Arabic Writing Skills That Can Be Enhanced Through Documentary Film}

From the SMEs responses in Table 2 on the enhancement of Arabic writing skills through documentary film, it is obvious that they agreed with 30 items that were adopted in writing skills (Mohamed \& Hussaini, 2011; Atiyyah, 2007; Toiemah, 1998). There are four sub skills in the questionnaire which are presented as content skill, organization skill, language style skill, and thinking skill. In the organization skill, all seven items are reported as high interpretation result with a mean score between 4.33 and 3.66. The same case is recorded in the thinking skill where all eight 
items revealed high interpretation result with the mean score between 4.08 and 3.50 . In contrast, the language style skill indicated very high interpretation result for two items with the mean score between 4.66 and 4.58, while the remaining six items scored high-level interpretation with the mean score between 4.25 and 3.83. Similarly, "skill in linking ideas" in content skill showed very high interpretation result with a mean score of 4.5, while the remaining six items indicated high-level interpretation with a mean score between 4.33 and 3.75 . The researchers also found that the writing skills can be developed from documentary film and are more related to the content skills and language style skills while the least is the organization skills in writing. These three skills are very important in the development of Arabic writing skill (Abd Al Bariy, 2010) and the content skills are one of the major problems faced by students (Mohamed \& Hussaini, 2011). Generally, it is also clear that the skill in using the standard Arabic and avoiding slang words, the skill in choosing words and structures that carry ideas, and the skill in linking ideas are among the items that scored the highest mean. The predicted results stated that learning from documentary films will help more in terms of suitable vocabulary and choosing ideas related to the writing topic.

Table 2 The Arabic Writing Skills that can be Enhanced through Documentary Film

\begin{tabular}{|c|c|c|c|}
\hline No & Items & $\begin{array}{l}\text { Mean } \\
\text { Score }\end{array}$ & Interpretation \\
\hline \multicolumn{4}{|c|}{ Skill in Content } \\
\hline 1 & Skill in linking ideas & 4.50 & Very High \\
\hline 2 & Skill in choosing ideas & 4.33 & \\
\hline 3 & Skill in using correct ideas and information & 4.33 & \\
\hline 4 & Skill in choosing a topic & 4.08 & High \\
\hline 5 & Skill in writing short report about a problem or an issue & 4.08 & \\
\hline 6 & Skill in expressing ideas clearly & 4.00 & \\
\hline 7 & $\begin{array}{l}\text { Skill in writing about sensitive issues regarding Arab } \\
\text { culture }\end{array}$ & 3.75 & \\
\hline \multicolumn{4}{|c|}{ Skill in Organization } \\
\hline 8 & Skill in developing ideas & 4.33 & \\
\hline 9 & Skill in presenting unified essay & 4.25 & \\
\hline 10 & Skill in writing conclusions & 4.16 & \\
\hline 11 & Skill in sequencing ideas & 4.08 & \\
\hline 12 & Skill in using a paragraph for each idea & 4.08 & High \\
\hline 13 & Skill in using accurate conjunctions & 3.91 & \\
\hline 14 & Skill in using footnotes correctly and consistently & 3.66 & \\
\hline 15 & Skill in using punctuation marks & 3.66 & \\
\hline \multicolumn{4}{|c|}{ Skill in Language Style } \\
\hline 16 & Skill in using standard Arabic and avoiding slang words & 4.66 & Very \\
\hline 17 & Skill in choosing words and structures that carry ideas & 4.58 & High \\
\hline 18 & Skill in using correct syntax & 4.25 & \\
\hline 19 & Skill in using correct writing style & 4.25 & \\
\hline 20 & $\begin{array}{l}\text { Skill in using the right grammar and language } \\
\text { rules }\end{array}$ & 4.16 & High \\
\hline 21 & Skill in completing structure elements & 4.00 & \\
\hline 22 & Skill in speed writing and accuracy & 3.83 & \\
\hline \multicolumn{3}{|c|}{ Skill in Thinking } & High \\
\hline 23 & Skill in recording observations & 4.08 & \\
\hline
\end{tabular}




\begin{tabular}{llcc}
\hline No & \multicolumn{1}{c}{ Items } & $\begin{array}{c}\text { Mean } \\
\text { Score }\end{array}$ & Interpretation \\
\hline 24 & Skill in declaring ideas & 3.91 & \\
25 & Skill in imaginative capacity & 3.91 & \\
26 & Skill in citation using literature evidence & 3.91 & \\
27 & Skill in power argumentation in defending an opinion & 3.75 & High \\
28 & Skill in intellectual dialogue and accepting views & 3.75 & \\
29 & Skill in identifying points of strength and weakness in & 3.75 & \\
& others' idea & 3.50 & \\
30 & Skill in showing respect for others' opinions & \\
\hline
\end{tabular}

\section{Suggested Areas to be Employed in the Future Research and Studies}

From the SMEs responses illustrated in Figure 3, with regard to suggested areas to be employed in the future research and studies, they agreed with the six areas of documentary films as suggested by Aufderheide (2007) and Bilal (2013) with a mean score between 4.83 and 3.42. It seems that almost all areas were agreed by all SMEs as very high and high interpretations. In addition, the SMEs suggested other areas of suitable documentary films such as science and technology, battle of the nations, social entertainment, and others. Besides that, teachers should consider the students' level and their interests. In addition, the researchers found that there are new areas suggested by the SMEs such as the area of science and technology, battle of the nation, and social entertainment.

"Battle of Nations Documentary film" E6

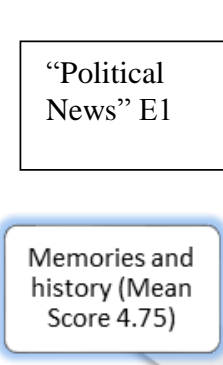

\begin{tabular}{|l|}
\hline "Science \\
Encyclo \\
pedia, \\
World \\
Atlas" \\
E1
\end{tabular}

Nature and environment (Mean Score 4.83)
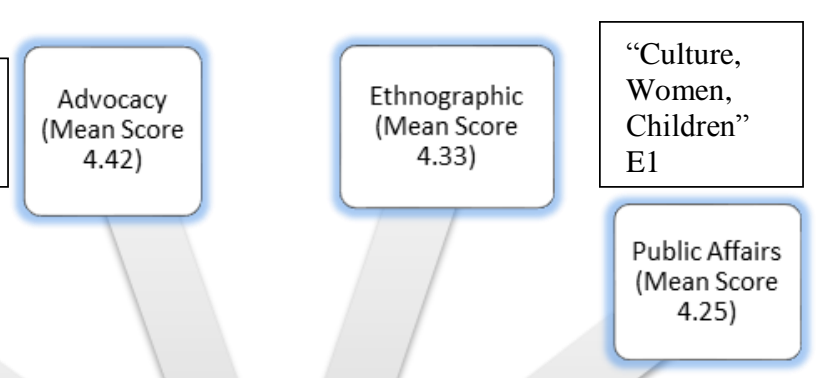

Public Affairs (Mean Score 4.25) Entertainment" E3 "Religious Lecture, Knowledge Session, Social" E1

Government Propaganda (Mean Score 3.42)

Figure 3 Suggested Areas to be Employed in the Future Research 


\section{Instructional Model to be Used in The Employment of Documentary Film}

From the SMEs responses shown in Figure 4 in relation to the instructional model to be used in the employment of documentary film, it is clear that all five items were accepted by SMEs with a high interpretation result and a mean between 3.58 and 4.25. The study has shown that the instructional model by Hasan Basri (2011) has scored the highest mean since the model includes the time allocation for every step in this instructional model. All these five instructional models were discussed in previous literature review. Besides, it is understood that there was no comment on the first model while the second and third models have been commented on how to present the film and the time allocation. Collaborative activity is credited in the fourth model while it is suggested that an experimental study should be done on the fifth instructional model. In addition, it is also clear that every model has its own strengths and weaknesses. Thus, SMEs predicted that the researchers can develop a new model by taking into account the five instructional models. Next, one SME suggested the use of two groups, control and experimental in an experimental study. Finally, the researchers found that there is a need to develop a new model based on all these five instructional models. With regards to the last five instructional models used in class, it can be understood that every model has its own strengths and weaknesses.

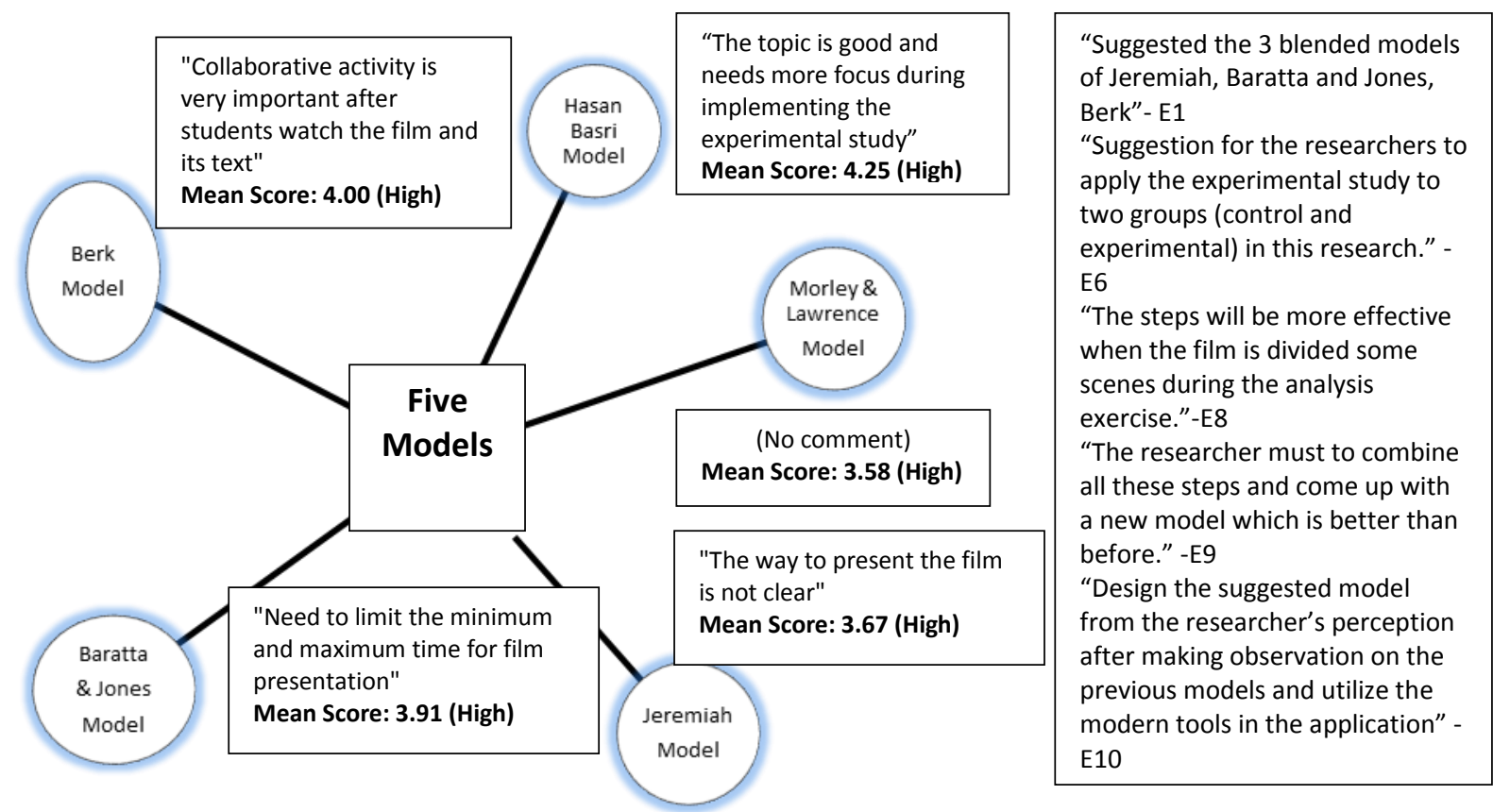

Figure 4 Instructional Model to be Used in The Employment of Documentary Film 


\subsection{CONCLUSION}

Based on the review of the literature, it is clear that the input of documentary films in language classes has been used for many years and its effectiveness has been proven by some studies in the field of second language learning. This is also supported by this study which highlights and promotes the use of documentary films in the writing skills classroom based on Arabic as a second language. Thus, this paper presents an analysis by twelve experts of ASL in Malaysian universities on the role and importance of documentary film program as multimedia language input in enhancing writing skills among ASL learners. The findings indicated that the SMEs recommended types of documentary film which are recommended to be utilized, categories of writing skill that can be developed, and appropriate instructional techniques which should be used in the classroom. Some studies in the field of English as a second language have employed this multimedia input in their language teaching and learning process.

In addition, from the experts' responses, the researchers note that there are thirty skills in the writing skill that can be developed by utilizing documentary film texts, namely, seven content skills, eight organizational skills, seven language style skills, and eight thinking skills. The experts have also recommended the listening criteria to documentary film texts based on the level of reading speed and careful selection of texts in order to fulfill the purpose of using this authentic language input. In general, the experts agree with this application but provided some constructive comments. In general, this study contributes to its employment in teaching and learning Arabic as a second language, especially in enhancing writing skills among Arabic non-native speakers who are learning Arabic in the non-native environment or outside the Arabic countries.

\section{ACKNOWLEDGEMENT}

This research project is funded by Research Management Centre, IIUM under the Research Initiative Grant Scheme from February 2016 until December 2017 under the leadership of Assoc. Prof. Dr. Abdul Rahman Chik as the principal investigator. Title of project: Developing an Instructional Model in Enhancing Productive Skills through Documentary Films for Learning Arabic as a Foreign Language in Malaysia (RM16,000). The project ID is RIGS 15-113-0113.

\section{REFERENCES}

Abd Al Bariy, M. S. 2010. Al Maharat Al Kitabiyyah Min An Nash'at Ila At Tadris. $1^{\text {st }}$ Edition. Amman: Dar Al Masirah Li An Nashri Wa Al Tauzi’ Wa Al Tiba'ah.

Alnufaie, M., \& Grenfell, M. 2012. EFL Students' Writing Strategies in Saudi Arabian ESP Writing Classes: Perspectives on Learning Strategies in Self-Access Language Learning. Studies in SelfAccess Learning Journal. 3(4): 407-422.

Amaya-Anderson, B. 2008. Film in Composition: Developing Critical Thinking Skills Through the Study of Film in First-Year Composition. Unpublished PhD Thesis. Pennsylvania: Indiana University of Pennsylvania. 
Anggraini, Y., Yasin, A., \& Radjab, D. 2014. Improving Students's Writing Skill of Narrative Text Through Video at Grade XII IPA 2 of SMAN 2 Bukittinggi. Journal English Language Teaching. 2(2): 78-92.

As-Sayyed, M. N. A. A. 2006. Lughatu Al Khitob Al I'lamiyy fi Dhouk Nazoriah Al Ittisoliah, Dirasah Uslubiyyah Lughawiyyah fi Nasyarat Al Akhbar Al Iza'iyyah. 1 ${ }^{\text {st }}$ Edition. Cairo: Dar al-Fikr alArabi Publishing.

Atiyyah, M. A. 2007. Tadris Al-Lughah Al-Arabiyyah Fi Dhou'Al-Kifayah Al-Adaiyyah. $1^{\text {st }}$ Edition. Amman: Dar Al-Manahij li An-Nasr wa At-Tauzi’

Aufderheide, P. 2007. Documentary Film a Very Short Introduction. Oxford, Oxford University Press.

Bahrani, T. 2013. Importance of Language Input in Language Learning. International Researh Journal of Applied and Basic Sciences. 6(10): 1376-1379.

Baratta, A., \& Jones, S. 2008. Using Film to Introduce and Develop Academic Writing Skills Among UK Undergraduate Students. Journal of Education Enquiry. 5(2): 15-37.

Berk, R. A. 2009. Multimedia Teaching with Video Clips: TV, Movies, Youtube, and MTVU in the College Classroom. International Journal of Technology in Teaching and Learning. 5(1): 1-12.

Bernardo, A. S. 2011. Reading What's Beyond the Textbooks: Documentary Films as Student Projects in College Reading Courses. ELT WorldOnline.com. 3, September, 1-12.

Bilal, A. A. 2013. Al Film at Tasjiliyy at Tilifizyuniyy Min Al Fikrah Ila As Syasyah. $1^{\text {st }}$ Edition. Damascus: Al Hai'ah Al 'Ammah as Suriah li Al Kitab.

Creswell, J. W. 2012. Educational Research: Planning, Conducting, and Evaluating Quantitative and Qualitative Research. $4^{\text {th }}$ Edition. New Jersey, USA: Pearson Education International.

Etikan, I, Musa, S. A., \& Alkassim, R. S. 2016. Comparison of Convenience Sampling and Purposive Sampling. American Journal of Theoretical and Applied Statistics. 5(1): 1-4.

Flower, L., \& Hayes, J. R. 1981. A Cognitive Process Theory of Writing. College Composition and Communication. 32(4): 365-387.

Haris, H. \& Abdullah, S. 2013. The Use of Documentary Video to Teach Writing News Item Text to the Tenth Grade Students in SMAN 4 Bangkalan Hasan Haris. Journal RETAIN Universitas Negeri Surabaya. 1(3): 1-9.

Hassan Basri, A. M. D. 2011. Teaching Writing News Item Text through Documentary Video at the Tenth Grade of SMA N1 Kaliwungu Kendal in the Academic Year of 2010-2011. Education Faculty. Unpublished Bachelor Thesis. Semarang: Walisongo State Institute for Islamic Studies.

Hutahaean, E. N. F., \& Ernidawati, T. 2013. Improving Students' Writing Achievement in the Report Text through Film. Journal of English Language Teaching of FBS-Unimed. 2(4): 1-16.

Indrasari, N. 2010. Improving Students' Writing Skill of Narrative Texts by Using Short Videos. Unpublished Bachelor Thesis. Teacher Training and Eduation Faculty, Sebelas Maret University, Surakarta.

Jeremiah, M. A. 1987. Using Television News and Documentaries for Writing Instruction. 38 th Conference on College Composition and Communication. March 1987: 1-13.

Joynt, R. E. 2008. Using Authentic Multi-media Material to Teach Italian Culture: Student Opinions and Beliefs. Unpublished PhD Dissertation, Austin: The University of Texas. 
Kasper, L. F. 2000. The Imagery of Rhetoric: Film And Academic Writing in the Discipline-based ESL Course. Teaching English in the Two-Year College. 28(1): 52-59.

Krashen, S. D. 1985. The Input Hypothesis: Issues and Implications. (n.d) London: Longman Group.

Mayer, R. E., \& Moreno, R. 1998. A Cognitive Theory of Multimedia Learning: Implications for

Design Principles. Proceedings of the SIGCHI Conference on Human Factors in Computing Systems, Los Angeles, (18-23 April 1998). 1-11.

Mayer, R. E., Heiser, J. \& Lonn, S. 2001. Cognitive Constraints on Multimedia Learning: When Presenting More Material Results in Less Understanding. Journal of Educational Psychology. 93(1): 187-198.

Mohamed, A. H., Hussaini, M. H. 2011. Kifayah Al-Kitabah Lada Hirriji Al-Jami'aat AlMahalliyyah Al-Maliziyyah: Dirasah An Wijhat An-Nazar Muhadhiri Al-Lughah AlArabiyyah. Prosiding Seminar Antarabangsa Pengajaran Bahasa Arab 2011 (SAPBA'11).

Morley, H. J., \& Lawrence, M. S. 1971. The Use of Films in Teaching English as a Second Language. Language Learning. 21(1): 101-103.

Oxford, R. L. 1990. Language Learning Strategies: What Every Teacher Should Know. $1^{\text {st }}$ Edition. New York: Newbury House Publisher.

Peacock, M. 1997. The Effect of Authentic Materials on the Motivation of EFL Learners. ELT Journal. 51(2): 144-156.

Popping, R. 2015. Analyzing Open-ended Questions by Means of Text Analysis Procedures. Bulletin of Sociological Methodology. 128(1): 23-39.

Reja, U., Manfreda, K. L., \& Hlebec, V. 2003. Open-ended Vs Close-ended Questions in Web Questionnaires. Developments in Applied Statistics. 19(1): 160-117.

Rohman, M. 2014. The Effectiveness of Using Documentary Films to Teach Written Report Text. Unpublished Bachelor Thesis. Education Faculty, Walisongo State Institute for Islamic Studies.

Shin, J., \& Cho, E. 2015. Characteristics of Convergence Learning Experience Using an Educational Documentary Film. Asia Pacific Education Review. 16(2): 213-223.

Snow, Z. 2012. The Cinematic Essay: Argumenative Writing and Documentary Film. Unpublished Masters of Arts English, Clemson University.

Soong, D. 2012. Using Documentary Films in Oral Interpretation Class What is the Appropriate Length? International Journal of Applied Linguistics \& English Literature. 1(6): 131-141.

Toiemah, R. A. 1998. Al-Usus Al-'Ammah Limanahij Taa'lim Muhadhiri Al-Lughah Al-Arabiyyah: I'daduha Tatwiruha Taqwimuha. $1^{\text {st }}$ Edition. Cairo: Dar Al-Fikr Al-‘Arabiyy.

Tg Ainul Farha, T. A. R., Abdul Rahman, C, Muhammad Sabri, S. \& Mohd Shukri, N. 2017. A Review of Documentary Film as Authentic Input in Enhanching Writing Skills in ASL Settings, Journal of Nusantara Studies. 2 (1): 99-110.

Tristy, R. T. 2010. Improving Students' Skill in Writing Report Text with All About Animals VCD. Unpublished Master Thesis. Faculty Languages and Arts, Semarang State University.

Verdinelli, S., \& Scagnoli, N. I. 2013. Data Display in Qualitative Research. International Journal of Qualitative Methods. 12(1): 359-381. 